\title{
IMAGE AND ITS MANUFACTURING IN HUMAN COMMUNICATION VIS-À-VIS THE TRANSLATION PROFESSION: THE IMAGE DYNAMISM OF THE POLISH SWORN TRANSLATOR OF THE ENGLISH LANGUAGE
}

\author{
MARLENA IWONA BIELAK
}

\begin{abstract}
It is claimed that the Polish sworn translator in his/her translating activities is subject to a complex processes of image manufacturing. Based on some important contributions to the problem of image generation, it is shown that the Polish sworn translator's practices within image generation suffer from being intuitive, not very careful and lacking cautious planning. It is also claimed that a successful image generation should be strengthened by proper cross-cultural conditioning.
\end{abstract}

Key words: image, sworn translator, translator's image awareness

\section{Introduction}

Effective communication, which constitutes the sine qua non of everyday human existence, is determined by a wide plethora of factors, a mindful approach to image and its manufacturing being one of them. In other words, individuals who want to communicate effectively must be capable of generating an image that will enable them 1) to function successfully within their own socio-cultural-communicative space and 2) move without restraint across various environments (i.e. diverse cultures, communities, ethnicities and communicative orders). For the above reasons the idea of image and its creation is of profound importance in professional commu- 
nication. Accordingly, there seems to appear a need to analyze the aforesaid issue with reference to communicators of different professions who reside in diverse cultures. In this paper the concept of image and its formation is approached in relation to the translation profession, with particular emphasis put on the process of image manufacturing regarding a sworn translator of the English language who is a representative of Polish culture. The term translator is understood both as an interpreter and a translator of written texts.

\section{Definition of image and preliminary views regarding the concept}

The term image originates from the Latin word imago which stands for a picture or symbol (Sampson, 1996, p. 15). The concept was popularized by Lipman (1922) who postulated that humans approach reality forming 'pictures in their heads' which represent simplifications of the complex nature of reality. Image is, therefore, subjective (Uścińska and Ciamciara, 2015, p. 90; Wongphudee, 2015, p. 59). Typically, the notion of image is interpreted as the general awareness of oneself/ourselves or the perception of a person, group or thing by the outer environment (Wójcik, 1997, p. 44); image may thus refer to individuals, groups or institutions. The concept in question may be also viewed as a collection of communicative techniques which result from intended and unintended decisions (Pluta, 2001, p. 32). Accordingly, image may be transformed under the influence of environmental factors with a view to adjusting it to the effect required by particular circumstances (Budzyński, 2002, p. 9). If a given image is to impress its receivers, the process of its manufacturing must be carefully planned (Worakijphokatorn, 1994). In sum, image may be approached from the static perspective (as the awareness of one's own identity or as a structure differentiating between images) or the dynamic one (as undertaking activities aimed at producing different images in the minds of receivers) (Puppel, 2016). Due to the fact that it is the latter framework that will be applied in the research part of the paper, a more thorough presentation of this proposal will be provided in the subsequent section.

\section{Image as a characterisitic of embodiments (Puppel, 2016)}

Puppel's approach (2016), whose elements have been also described by Bielak (2017, pp. 49-53), is founded on the idea that image and image-related activities (i.e. image maintenance, manufacturing and dissemination) represent one of the fundamental elements of life dynamics typical of embodiments (defined as a biological, social and cultural entities). The above view is underlain by the assumption that 1) each embodiment is in possession of two interrelated properties, i.e. look and its 
perception and 2) everything in an embodiment contributes to the process of creating the image of this embodiment. With reference to the above rules, the notions of the image universality law and global image system are introduced (Puppel, 2016, p. 110).

According to Puppel (2016, p. 111), the definition of image is twofold, i.e. the notion in question may be viewed both as a state and as a concept approached in terms of its dynamics. Image as a state represents the embodiment's awareness (either higher or lower) regarding their own identity or the design which distinguishes between images. Image dynamism, in turn, refers to the continuous process of performing actions aimed at creating images in the receiver's mind with the intention of defending the embodiment or reaching/maintaining image aesthetics.

Due to its universality, the notion of image plays a vital role both in the realm of plants and animals and in the world of humans. Significantly, with reference to man and his/her communicative behaviors, image is conditioned not only by biological properties but also by socio-cultural aspects that impose socio-cultural utility on the concept under analysis. The existence of the aforementioned socio-cultural usefulness, in consequence, imposes the necessity of manufacturing and maintaining images that are most favorable for human communicators. In other words, the process of generating and maintaining images by human embodiments is aimed at reaching image success in various communicative orders, communities, ethnicities and cultures. The success in question is to be identified with image attractiveness that, in turn, forms some background for the prosperity of man as an individual and as a species (Puppel, 2016, p. 120).

The image of man in the static perspective refers to: 1) the awareness of communicators in terms of possessing their own mental image, i.e. a given opinion of oneself, and 2) the awareness of the need to apply one's mental image to produce a given impression among others. Therefore, the image of man as a state signifies the static structure of self-representation determined by the co-existence and co-operation of four ontological-constructive features: 1) the awareness of a communicator regarding the significance of his/her own image (I), 2) feelings associated with one's own image (F), 3) one's own evaluation of image (A) and 3) one's own mental picture of image $(\mathrm{P})$. The above structure comprises the Image Complex of Man I-F-A-P (Puppel, 2016, pp. 116-117).

The image of man in the dynamic perspective refers to the communicator's awareness of the possibility of taking actions regarding manufacturing, maintaining and disseminating one's static structure of self-representation determined by its four ontological-constructive features. The above actions, performed via a multitude of means, serve the function of a generative mechanism. The mechanism in question involves the application of a fixed set of rules that introduce corrections to one's own image complex in order to guarantee its positive reception by others. The reproduction of a given image complex via a variety of means represents the dynamics of image strategies based on image comfort subcategorized into motion, phonic, 
visual and olfactory types of comfort (Puppel, 2016, pp. 114-115). Notably, the implementation of image strategies should aim to achieve the high level of image effectiveness defined as high performance with regards to affecting other communicators (Puppel, 2016, p. 116).

The category of image strategies implemented by man comprises image modality strategies and figure strategies. In the former group one can differentiate between three types of strategies: 1) mono-modality visual strategies (engaging only one modality, e.g. only the auditory-vocal modality, or only the visual-tactile modality or, less frequently, only the olfactory modality), 2) bi-modality visual strategies (involving the simultaneous use of two modalities - mainly the auditory-vocal one integrated with the visual-tactile modality) and 3) hybrid visual strategies (based on the combination of image strategies embodying the ear-eye dyad joined with the application of a technological medium). The latter group of image strategies consists of the full-figure image strategy and the façade image strategy. Importantly, image modality strategies and figure strategies are frequently joined, which guarantees the most successful presentation and perception of the image complex (Puppel, 2016, pp. 116-118).

The effectiveness of image, achieved by implementing the image strategies described above, is also determined by the image policy founded on two criteria: 1) image strength and 2) its durability. The latter criterion signifies the long duration of image, whereas the former refers to the strong presence of image that can be expressed by intensity and maximization of such image parameters as its size, color, smell, weight, etc. (Puppel, 2016, pp. 118-119).

Simultaneously, image creation is subject to the basic principles of economy, i.e. the rule of demand and supply and macroeconomic rules. In the macroeconomic perspective the possession of an image by a communicator may be viewed as having an awareness capital spread over different image constituents, which are related, for example, to communication orders classified as:

I - the primary/natural oral/vocal human communication order (NHCO) which is primarily based on the audio-vocal modality in the 'orality' dimension of communicator performance and supported by the visual-tactile modality in the 'gestural' dimension of communicator performance (AVO; the carrier: the human body)

II - the augmented written/graphic human communication order (AHCO), secondary to the NHCO, which is based on the visual-tactile modality (VIT; the carrier: the writing/print)

III - the AHCO with its major extension in the form of the primary hybrid human communication order (PHHCO), where the two modalities are used jointly in a multiplicity of uses (the carriers: the human body, the writing/print) $\mathrm{IV}$ - the AHCO with its further extension in the form of the secondary hybrid human communication order (SHHCO), where the primary 'orality-gesturality' 
connection has been strengthened by other technologically more and more sophisticated media, such as the quickly expanding electronic media, resulting in the establishment of the most sophisticated combinatorial communication systems (the carriers: all the multimedia) (Puppel, 2012: 9-10).

The ability of manufacturing image in changeable communicative contexts may be, in turn, juxtaposed with investing the awareness capital and interpreted as the liquidity of the capital in question (Puppel, 2016, pp. 119-120). The aforesaid liquidity is underlain by the basic assumptions of the image policy presented above which may be incapsulated in the principle: "more, longer, stronger, more beautifully" (Puppel, 2016, p. 120).

\section{Image and professional success}

The present times are perceived as the era of image (Bobrowska and Garska, 2012, p. 148; Kunczik, 1996; Uścińska and Ciamciara, 2015, pp. 90-92). In consequence, the problem of image and its management is of vital importance to individuals who intend to succeed in their professional life. Since the impact of image and its creation on professional success is generally considered as exceedingly significant, the issues in question have been analyzed with reference to different professional fields and professions. To exemplify, the problem of celebrity image building has been approached, among others, by Czaplińska (2015) and Wongphudee (2016). With regard to shaping the image of an employer, one can consult Bartkowiak and Szłapińska (2014). The notion of successful corporate image building has been discussed, inter alios, by Andrzejewski (2003), Budzyński (2002), Cwalina, Falkowski, and Newman (2011), Dolphin (2000), Knap-Stefaniuk (2015), Ko, Hwang, and Kim (2013), Shimp (2010) or Smith and Taylor (2004). The image of teachers has been analyzed, inter alios, by Czepiec-Mączka (2000), Famuła (2003), Judge (1995), Korczyński (2002), Stróżyński (2001), Swetnam (1992) or Świder (2002), whereas its manufacturing on internet sites has been presented by Bielak (2017). In terms of manufacturing the image of politicians, one can point to publications by Cichosz (2003), Dobek-Zaręba (2011), Harvey \& Young (2012), Jeziński (2011), Schill (2012) or Wheeler (2013) among others. Generally speaking, the idea of image and its management can be analyzed with reference to each particular profession, inclusive of the translation one.

\section{The translator's image and its manufacturing}

Every translator, as an embodiment, is subject to the image universality law and, accordingly, possesses an image that constitutes an element of the global image system. The image in question may be assumed to belong to the subsystem of global 
professional images further divided into profession-specific categories comprising culture-specific classes. Each translator, therefore, possesses his/her own look and its perception which are determined by the culture in which the translator functions. In consequence, the translator's image, which originates from everything that represents the translator per se and his/her work, is subject to strong cultural conditioning.

The translator's image dynamism is focused on achieving image success (identified with the translator's image attractiveness) in different communicative orders, cultures, ethnicities and communities. The basic criterion that conditions the aforesaid success is the high level of translating skills represented by the translator. Advanced translation skills are mainly designated by the capability of applying appropriate language registers and translation approaches in different translation contexts.

The range of registers translators encounter in their job is exceedingly wide. To exemplify, community interpreting, as a very broad discipline based on different types of discourse, requires the use of various linguistic jargons and styles, whereas the translation of such literary genres as poetry generally involves the use of aesthetically-oriented forms of language. Totally different registers may be identified in the case of legal, medical, technical or linguistic texts. In consequence, the translator's ability to apply a huge number of registers signifies exceedingly advanced linguistic skills, which in turn translates into a high degree of professionalism contributing to the translator's image success.

The selection of the translation approach is strongly determined by the type of commission the translator receives. To exemplify, conference interpreting ought to be characterized by the high level of text equivalence and faithfulness, the interpreter's neutrality and uncommitment and rest on advanced rhetoric skills. The conference interpreter should, therefore, attempt to be "invisible or transparent" (Tryuk, 2006; Bielak, in print). In the case of community interpreting, the interpreter may be perceived as an interaction participant who performs different roles (Wadensjö, 1998), which changes the attitude to the role of precision in translation. In consequence, community interpreters frequently do not provide word-for-word translations. They are not "transparent or invisible" but give their own explanations, ask additional questions or omit certain elements of the source text such as curses (Tryuk, 2006; Biernacka, 2014; Bielak, in print). In the case of functional texts such as guides or advertisements, translators should take into consideration the purpose of their translations (cf. Vermeer, 1978; Reiß and Vermeer, 1984; Holz-Mänttäri, 1984; Bielak, in print). Examples of the above type may be multiplied. Due to the fact that translation approaches which should be applied in different translation environments are extremely diversified, it may be assumed that translators who successfully adjust their translation methods to a given translation context represent a high level of translating skills, which provides them with image attractiveness. 
High translation skills determining the translator's image success may be officially certified. Regulations with reference to obtaining the rights of certified translators differ from country to country. In Poland it is The Act of 25 November 2004 that " $(. .$.$) defines the conditions and procedure for obtaining and losing the right to$ practise the profession of sworn translator, as well as the rules for practising the said profession" (Act of 25 Nov. 2004 on the Profession of Sworn Translator, Art. 1.1). In accordance with the above act, the sworn translator is in possession of advanced skills certified by two types of diplomas, i.e. he/she must be a natural person who:

(...) is a graduate of higher education Magister's studies in the field of philology or is a graduate of higher education Magister's studies in another field and post-graduate studies in the field of translation and/or interpretation, appropriate for the given language;

(...) has passed an examination in the field of translation and interpretation from the Polish language into the relevant foreign language and from that foreign language into the Polish language; hereinafter said examination shall be referred to as the "examination for sworn translators" (Act of 25 Nov. 2004 on the Profession of Sworn Translator, Art. 2.1.5, 2.1.6)

The image attractiveness in question is also conditioned by the translator's respectful attitude towards his/her clients, which may be expressed by:

- a tidy flat (in the case of freelance translators it frequently performs the function of an office),

- a well-prepared offer with details regarding translation preparation,

- a natty translation copy handed to a client,

- a polite attitude towards clients (even towards those who behave in an impolite way),

- a neat and tidy look of a translator - freelancers, while working at home, may be occasionally found slovenly (Szulczewska, 2014).

Conversely, a neglecting attitude towards clients, which has a disastrous impact on the translator's image, may be exemplified by:

- swearing,

- missing the deadline,

- promising things that are impossible to be achieved,

- irresponsibility,

- bad organization of work,

- problems with keeping translated information confidential (Wpływ błędów na wizerunek, n.d.).

Notably, the translator's image success/attractiveness may be reached if the presentation of advanced translation skills and a well-mannered attitude to clients are demonstrated by the translator via appropriately adjusted image strategies based on image comfort. It must be highlighted that at present it is especially the group of hybrid visual strategies that is of vital significance in translation business. Nowa- 
days, translating, contacting clients or advertising translation offers seems to be hardly imaginable without the use of different technology media.

The application of image strategies by the translator ought to be directed at reaching a high degree of his/her image effectiveness, which is strongly dependent on the translator's image attractiveness (i.e. the latter increases the impact of the translator's image on his/her potential clients). In consequence, the translator's image effectiveness, reached via disseminating the translator's attractive image, may be measured in relation to the number of translation orders received by him/her (which translates into professional success).

The liquidity of the translator's awareness capital, which is aimed at achieving maximum benefits, may be fairly large due to the fact that it may be held in different communication orders. The specify, contacts with clients may involve all the four communication orders, whereas written translation may be based on 1) the joined use of the graphic and natural human communication order or 2) the application of graphic and primary communication order supported by multimedia. Interpreting may engage the natural human communication order, but it may also rest on the combined use of the graphic and natural human communication order if it involves note-taking. Notably, the process of investing the translator's image awareness capital in various communicative orders facilitates the full realization of the rule expressed by Puppel (2016, p. 120) as "more, longer, stronger, more beautifully".

The translator's image and its manufacturing, just as all elements of communication, are strongly culturally determined. In this paper due attention will be paid to the process of building the translator's image in Polish culture. The research undertaken for the needs of this work, which is demonstrated in the following part of the paper, will be based on the dynamic approach to image proposed by Puppel (2016) which, as already mentioned, is defined as undertaking a vast number of activities aimed at producing different images in the mind of receivers.

\section{Research method}

The research constitutes a qualitative analysis and is based on a case study. It is aimed at analyzing selected aspects of image dynamism with regards to one sworn translator of the English language who is of Polish nationality and resides in Poland. In other words, it attempts to show how the sworn translator's image, in the context of Polish culture, is manufactured, maintained and disseminated in view of securing its positive reception by potential clients. The research seeks to find answers to the questions presented below.

The main research question:

1. How can the image of the Polish sworn translator under analysis be described in terms of its dynamism? 
Supporting enquiries:

1. Can the translator be treated as a full professional?

2. What image strategies are applied by the Polish sworn translator in the process of manufacturing, maintaining or disseminating her image a) while performing translation activities and $b$ ) in her contacts with clients?

3. Are the image strategies applied by the Polish sworn translator founded on image comfort?

4. Does the application of image strategies by the translator result from any preplanned scheme?

5. Does the process of manufacturing the translators' image result in the success/attractiveness of the image in question?

6. What is the strength and duration of the Polish sworn translator's image?

7. How can one characterize the liquidity of the translator's awareness capital with reference to communication orders?

8. Does the manufacturing, maintaining and disseminating of the Polish sworn translator's image result in image effectiveness?

The research data was collected by applying the method of interviewing. The interview conducted with the translator under analysis lasted about two hours. Its scenario, presented in the appendix, consisted of 12 enquiries and initial information (directed at the interviewee) regarding the research objectives and its anonymity.

\section{Research results}

The results of the research, which consist of the information gathered during the interview with the Polish sworn translator of the English language, will be presented with reference to the questions of the interview scenario.

1. Interview scenario question 1:

Could you describe your qualifications and professional experience?

- The translator is a graduate of MA studies in the field of English Philology. She was granted the right to practice the sworn translator's profession at the beginning of her professional career, i.e. three years after her graduation. She did not take any exam (at that time no examination for sworn translators was obligatory - there were very few English philology graduates and very few people who spoke any English at all. Additionally, English philology studies were elitist and a diploma in this field of study represented high qualifications. Examinations for sworn translators were introduced when studies in Poland lost their elite character and began to represent mass education). Additionally, she holds a $\mathrm{PhD}$ in linguistics and at present she is preparing her habilitation thesis.

- Her professional experience includes translation activities and teaching both EFL at various levels and academic theoretical subjects in the field 
of English philology. She has been professionally very active for over 20 years. As a translator, she works as a freelancer.

2. Interview scenario question 2 :

Could you describe your professional achievements?

- One of her basic professional achievements of the translator is that the quality of her work is high. The basic rule she follows while translating is that in cases of doubts she always consults numerous dictionaries, on-line sources or experts in a given field. She never leaves a given problem unresolved.

- Additionally, the lady never accepts a translation commission if the deadline required by the client is too short, which makes reaching the appropriate standard of translation impossible.

- The high quality of her work also results from the fact that the translator is focused on developing her competences, inclusive of proceeding with her academic career (which also enriches her as a translator). The lady highlights that she has been constantly learning new things. As a result, the progress she has made in terms of developing her translation skills is enormous. To exemplify, at the beginning of her professional work one could identify situations (but not numerous) when the results of her work were not fully perfect, whereas at present such imperfections do not occur.

3. Interview scenario question 3 :

What types of texts do you usually translate?

- In her professional career the translator has worked both as a translator of written texts and as an interpreter. In terms of written translations, she has mainly translated documents that required the application of different registers, e.g. legal, business, financial, administrative or medical ones. With reference to different types of oral translations, the lady has experience in community interpreting, with particular reference to court interpretation.

4. Interview scenario question 4:

Do you accept all translation commissions?

- The lady does not accept all translation commissions for two reasons. The first one is that some of them are too time consuming, which makes them not profitable if you take into consideration the bids for each translation page. The other is that her time is limited (she has numerous professional duties) and she does not always have enough time to work on a translation (especially when the commission is urgent, i.e. the deadline suggested by the client is very short).

5. Interview scenario question 5:

Do you need more translation commissions?

- The translator does need any additional work, i.e. she is provided with the number of translation commissions she needs. She is simply not capable of taking on more translation responsibilities. 
6. Interview scenario question 6:

How come you have got enough/not enough translation commissions?

- The lady thinks that she has got enough translation commissions thanks to the fact that:

a. she has a good reputation,

b. she is known among the local population - she has been working in the place of her residence (which is not a very big city) for a very long period of time - over 20 years.

7. Interview scenario question 7 :

What activities constitute the process of translating/interpreting performed by you?

- In the case of written translations, the lady opens her computer, translates the text she has been provided with and prepares its printed copy that will be passed to a client.

- The preparation of a hand-written copy of translation is exceedingly rare but there are cases when she is asked by colleagues to prepare a handwritten, on-the spot translation of, for example, the title of an academic paper.

- In the case of certified translations, each copy begins with the translator's personal data (her name, surname, address, phone number) and information regarding the translation (the language of the source text is specified). At the end of the copy there appears a note confirming that the translation is in accordance with the original text (the language of the original is also specified here). The final information also includes the number of translation pages (one translation page amounts to 1125 characters), the price that has been charged and the date. Each page of the translation is signed by the translator and stamped (the stamp includes the translator's name, surname and ministerial number confirming the right to certify documents).

- While translating, the lady consults numerous dictionaries (mainly internet ones), visits translation fora and enters academic papers to understand the meaning of certain terms (e.g. medical or legal ones). She does not make use of any translation computer programs as she considers them not fully reliable.

- As far as interpreting is concerned, the lady comes to the place where she is going to interpret and, subsequently, she performs her duties. So far she has mainly participated in community interpreting, where she acted as an interaction participant, i.e. she did not provide "word-for-word" translations, translated only the essence, asked extra questions and provided her own explanations. Sometimes she takes notes while listening to the text that she is going to interpret in a moment. 
8. Interview scenario question 8:

How do you advertise your translation offer?

- The translator has displayed her name and contact details on a board placed next to her house door (the information is transparently and aesthetically arranged).

- She does not specially focus on presenting her translation offer in virtual space, i.e. the translator neglects advertising her name on Facebook or any other social websites and has no official translator's website with the precise description of what she offers. Her name (as the name of a translator) appears in virtual space only in one context - it is the ministerial list of sworn translators.

- Notably, the translator's name appears on-line with reference to her other activities, i.e. her academic career accompanied by teaching and administrative duties.

- The basic reason for not advertising her translation offer via virtual space in a variety of ways is that she does not look for additional work. Since translation is not her only job, she can hardly meet deadlines when she combines her regular employment duties and translations.

- The translator highlights that if she needed more work, her translation offer should be definitely popularized more intensively on-line.

9. Interview scenario question 9:

Could you describe your contacts with clients?

- The translator's clients either contact her via phone, e-mail or visit her at home to discuss translation arrangements. They also come to her house to leave the text that is to be translated or send a copy of it via e-mail. When the translation is ready, the translator informs the client about it either via phone or by e-mail. Then the client usually comes to her at home to collect it. Occasionally, the translated text is sent via traditional post. Clients are provided with an invoice and, in the case of a certified translation, they confirm its receipt by signing the register of translations.

- The translator's house that functions as an office is clean and tidy.

- Additionally, the translator tries to look tidy and well-dressed and attempts to be always polite towards her clients (although their behaviors are very controversial sometimes).

- Her clients are always asked to come in and sit.

- The printed translation that is handed to a client is always natty.

- E-mails sent to her clients are always written in formal language and conform to all the rules of Polish politeness.

10. Interview scenario question 10 :

Do you remember any situations when the way you are perceived by others was negatively influenced in any way? 
- The lady emphasizes that she is only a human, which means that she cannot be fully perfect.

- Accordingly, once or twice in her professional career, the translator failed to remain calm and reacted unprofessionally (i.e. aggressively) to the impolite behavior of her client.

- Several times in her professional life she has been unexpectedly visited at home by a client when her look was not perfectly neat and tidy.

- While she was entering her professional path (and lacked experience), the quality of translation she provided was definitely lower than it is now.

11. Interview scenario question 11:

Have you planned the process of creating your image in any way?

- The lady has not prepared any plan of building her image. She has not even though of it. She just performs her everyday activities and duties the best she can.

The research results presented above constitute material that must be further interpreted. The aforementioned interpretation, which is to be presented in the subsequent section in the form of a list of statements, will result in establishing the image dynamism of the translator under analysis.

\section{Analysis of the research results}

The interpretation of the research material will be presented with reference to the supporting research enquiries, which will provide background in order to answer the main research question regarding the dynamism of the image of the translator under analysis.

1) The translator can be treated as a full professional thanks to her high linguistic competences which result from good education, wide professional experience (including translation, teaching or academic development) and the attitude centered on broadening her knowledge. Her professionalism is also represented by high translation competences (the translator's experience in translating legal, business, financial, administrative or medical documents signifies very advanced translation skills). One more factor that points to the translator's professionalism is her orientation on the high quality of translation and contacts with clients.

2) Therefore, the translator's image may be classified as the type of image determined by professionalism.

3) The aforementioned image is manufactured, maintained and disseminated via the application of diverse types of image strategies. Hybrid visual modality strategies are used by the Polish sworn translator, for example, while contacting clients, whereas bi-modality visual strategies are applied by her 
with reference to interpreting. The use of the mono-modality visual strategy in her image manufacturing, maintaining and disseminating is exemplified by the presence of the board on the translator's house with her contact details, whereas the combination of image modality strategies and figure strategies occurs in the case of contacts with clients. The process of preparing a written translation by the lady involves either the application of hybrid visual modality strategies or bi-modality visual strategies.

4) All the types of image strategies applied by the translator, by and large, rest on image comfort (the few occurrences of comfort deficiencies mentioned by the lady do not impair the general comfortability of her image).

5) The application of different image strategies does not result from any premediated scheme. In other words, the manufacturing of the translator's image seems to be intuitive or even unconscious.

6) The professionalism-rooted image of the translator is therefore intuitively manufactured, maintained and disseminated by means of different categories of image strategies based on image comfort.

7) The professionalism and comfort which determine the image in question enable one to classify the latter as successful/attractive.

8) The translator's image in the place of her residence is durable as she has been translating in the local area for over 20 years (which constitutes a very long period of the existence of her image in the local space). The durability of her image in virtual space is also of long duration due to the long presence of her name on the on-line ministerial list of sworn translators.

9) The image under analysis is strong in the local space. The maximization of her image may be attributed to the following aspects: 1) the lady possesses the right to practice the profession of sworn translator (which is viewed as prestigious and which represents high translation competences), 2) she has a good reputation, 3) she is professionally active, 4) her name and contact details are displayed on her house. All the above factors contribute to the intensive presence of the translator's image in the market.

10) However, the existence of the translator's image in virtual space is not based on the high level of strength. The low degree of strength results from the fact that 1) the translator's name is present virtually only in one translationrelated context, i.e. the Polish ministerial list of sworn translators, 2) other contexts in which the lady's name occurs on-line are associated with her remaining professional activities, 3) the image under analysis is not manufactured and disseminated via social websites such as Facebook or Twitter or via an official personal website devoted to translation activities.

11) The above differences in image strength in local and virtual space suggest the existence of various degrees of liquidity of the translator's awareness capital with reference to diverse communication orders. 
12) In other words, the liquidity of the Polish sworn translator's awareness capital is high with reference to: 1) the natural human communication order that is applied in the case of contacts with clients and interpreting, 2) the written/graphic communication order that pertains to printed or written copies of translated texts or other documents that are produced during translationrelated activities, and 3) the primary hybrid communication order that is used while contacting clients, preparing translations of written texts and note-taking during interpreting.

13) With reference to the secondary hybrid human communication order (SHHC), which is supported by the use of technological devices, the liquidity of the Polish sworn translator's awareness capital is considerably limited, i.e. the translator contacts/is contacted by clients by means of the SHHC and her personal details are disseminated in virtual space thanks to the on-line Polish ministerial list of sworn translators but her translation offer is neither advertised by means of social media nor demonstrated on a personal website, which considerably limits the process of the translator's image manufacturing.

14) The limited liquidity of the Polish sworn translator's awareness capital is caused by the fact that the translator has got enough translation commissions and, in consequence, faces no need for increasing the liquidity aimed at achieving the maximum benefit.

15) Since the translator has got enough translation commissions, it is assumed that the manufacturing, maintaining and disseminating of the Polish sworn translator's image, which represents the type of liquidity described above, results in image effectiveness.

16) Taking into consideration the above analysis, the image dynamism of the Polish sworn translator may be described as follows:

- the manufacturing of the image under analysis is intuitive, i.e. the process is not carefully and cautiously planned,

- the image in question is manufactured to a large extent with reference to the professionalism of the translator,

- the manufacturing relies on the use of different types of image strategies based, by and large, on image comfort,

- the processes described above give rise to the creation of the image which is successful/attractive,

- the dissemination of the successful/attractive image in question is strongly supported by the translator's image durability,

- the dissemination of the successful/attractive image of the Polish sworn translator is also accompanied by the high degree of her image strength in the local space. Importantly, the strength of the Polish sworn translator's image does not embody virtual space, 
- the liquidity of the Polish sworn translator's awareness capital is high in relation to 1) the natural human communication order, 2) the written/ graphic communication order and 3) the primary hybrid communicative order, whereas it is limited with reference to the secondary hybrid human communication order.

- the aforesaid image manufacturing, maintaining and disseminating results in the sufficient number of translation commissions, which is interpreted as image effectiveness.

17) In the face of the need for more work, the Polish sworn translator should increase the liquidity of her awareness capital with reference to the secondary hybrid human communication order. Her professional offer should be advertised quite intensively by modern technology-oriented media, i.e. it may be placed on a variety of internet websites, inclusive of social networking sites that enjoy great popularity and seem to be ever-expanding (cf. Boaz and Guan, 2017).

18) In other words, the Polish sworn translator, in the process of increasing the liquidity of her awareness capital, should rely on the determining role of media in shaping the communicative face of the present world (c.f. Avenbeck-Lietz, 2014; Couldry and Hepp, 2017; Lundby, 2009; 2014). Nevertheless, such a process cannot be intuitive and unconscious but carefully planned. Additionally, it should resemble (at least to some extent) the image manufacturing of celebrities whose activities are aimed at gaining media coverage (c.f. Panis and Van den Bulck, 2014).

19) Notably, while disseminating her image in the way suggested above, the lady must remember about adjusting her offer to the culture-specific determinants of media use (c.f. Gezduci and d'Haenens, 2007) characteristic of the communicators comprising her target group (i.e. potential clients). Since the translator specializes in Polish-English and English-Polish translations, her attention should be paid to the rules governing the use of the media in Polish and English culture.

20) As a final note, it must be highlighted that the above ideas associated with increasing the liquidity of the translator's awareness capital may be introduced in case any need for more translation commissions arises.

\section{Conclusions}

Human image is a universal phenomenon which results both from the biological nature of man and specific socio-cultural conditioning. Its socio-cultural utility is of vital significance in communicative space but not every human communicator is aware that he/she is in possession of such a significant presentation and mediatory 
tool which, despite its transitory nature, is always available. Accordingly, it seems tempting to suggest that in higher education curricula of each faculty there should be included courses devoted to image, its manufacturing, maintenance and dissemination. It must be also highlighted that image dynamism is subject to cultural conditioning, which points to the necessity of describing the cross-cultural characteristics of image building in the case of each profession. The description of the image dynamics of the Polish sworn translator, therefore, may be approached as initiating the cross-cultural analysis of the global system of interacting images.

\section{References}

Act of 25 November 2004 on the Profession of Sworn Translator. Journal of Laws of 27 December 2004. Poland (2004). Retrieved June 17, 2017. http://www.mc-tlumaczenia.pl/files/file/PolishSworn TranslatorAct(27_1_2005).pdf

Andrzejewski, P. 2003. Sztuka budowania wizerunku osób, firmy i instytucji. Poznań: Forum.

Averbeck-Lietz, S. 2014. "Understanding mediatization in "First modernity": Sociological classics and their perspectives on mediated and mediatized societies". In Lundby, K. (ed.). Mediatization of communication. Handbook of communication science 21. Berlin/Boston: Mouton de Gruyter. 109-130.

Bartkowiak, M. and J. Szłapińska. 2014. „Znaczenie budowania wizerunku pracodawcy na nowym rynku pracy”. Dyskurs Młodych Andragogów 15. 25-38.

Bielak, M.I. 2017. "Image in communication: Polish high school students and teachers vis-à-vis the dynamic aspects of their image on the official internet website of their school". Scripta Neophilologica Posnaniensia XVII. 49-59.

Bielak, M.I. (in print). The translator's identity vis-à-vis higher education curricula.

Biernacka, A. 2014. Ttumacz w rozprawie sądowej. Warszawa: Wydawnictwo Naukowe IKL@.

Boz, N. and S.A. Guan. 2017. "Your profile is so rad: Self-presentation strategies in Turkish adolescents". Communications. The European Journal of Communication Research 42 (1). 23-46.

Budzyński, W. 2002. Zarzadzanie wizerunkiem firmy. Warszawa: Poltext.

Bobrowska, A. and M. Garstka. 2012. "Elementy kreacji wizerunku podmiotu politycznego w rzeczywistości wyborczej”. Colloquiom Wydziału Nauk humanistycznych i Społecznych. Kwartalnik II/2012. 147-164.

Cichosz, M. 2003. Autokreacja wizerunku polityka na przykładzie wyborów prezydenckich $w$ III RP. Toruń: Wydawnictwo Adam Marszałek.

Couldry, N. and A. Hepp. 2017. The mediated construction of reality. Cambridge, Malden, MA: Polity Press.

Cwalina, W., Falkowski, A. and B.I. Newman. 2011. Political marketing: theoretical and strategic foundations. Armonk, NY: M.E. Sharpe.

Czaplińska, P. 2015. „Strategia budowania wizerunku osób znanych”. In: Grzegorczyk, A. (ed.). Perswazyjne wykorzystanie wizerunku osób znanych. Warszawa: Wyższa Szkoła Promocji, Mediów i Show Businessu. 8-38.

Czepiec-Mączka, A. 2000. „Wizerunek nauczyciela w opinii uczniów”. Problemy OpiekuńczoWychowawcze 2000/8. 21-23.

Dobek-Zaręba, A. 2011. Wizerunek polityka w III RP: kreacje, instrumentarium, kompetencje komunikacyjne. Rzeszów: Wydawnictwo Uniwersytetu Rzeszowskiego. 
Dolphin, R. 2000. Fundamentals of corporate communications. 2nd edition. London/New York: Routledge.

Famuła, A. 2003. „Nauczyciel w oczach gimnazjalistów“. Nauczyciel i Szkoła 2003/3-4. 139-148.

Gezduci, H. and L. Haenens. 2007. "Culture-specific features as determinants of news media use". Communications. The European Journal of Communication Research 32 (2). 193-222.

Harvey, J. and R. Young (eds.). 2012. Image-building in Canadian municipalities. Montreal/Kingston: McGill-Queen's University Press.

Holz-Mänttäri, J. 1984. Translatorisches Handeln: Theorie und Methode. Helsinki: Suomalainen tiedeakatemia.

Jeziński, M. 2005. „Wizerunek polityczny jako element strategii wyborczej”. In B. Dobek-Ostrowska (ed.). Kampania Wyborcza: marketingowe aspekty komunikowania politycznego. Wrocław: Wydawnictwo Uniwersytetu Wrocławskiego. 115-132.

Judge, H. (1995). "The images of teachers". Oxford Review of Education 21(3). 253-265.

Knap-Stefaniuk, A. 2015. "Kształtowanie wizerunku współczesnej firmy - wybrane zagadnienia”. ZNUV 44(6). 108-119.

Korczyński, S. 2002. Obraz nauczyciela. Opole: Wydawnictwo Uniwersytetu Opolskiego.

Ko, E., Hwang, Y.K. and E.Y. Kim. 2013. "Green marketing functions in building corporate image in the retail setting". Journal of Business Research 66(1). 1709-1715.

Kunczik, M. 1996. Images of nations and international public relations. Mahwah/New Jersey: Lawrence Erlbaum Associates, Inc.

Lipman, W. 1922. Public opinion. New York: Harcourt Brace.

Lundby, K. (ed.). 2009. Mediatization: concept, change, consequences. New York: Peter Lang.

Lundby, K. (ed.). 2014. Mediatization of communication. Berlin/Boston: Mouton de Gruyter.

Panis, K., and H. Van den Bulck. 2014. "In the footsteps of Bob and Angelina: celebrities' diverse societal engagement and its ability to attract media coverage". Communications. The European Journal of Communication Research 39(1). 23-42.

Pluta, E. 2001. Public relations - moda czy konieczność? Teoria i praktyka. Warszawa: Twigger.

Puppel, S. 2012. "The human communication orders and the principle of natural language sustainability“. Oikeios Logos 9. 1-14.

Puppel, S. 2016. "Kuźnia Hefajstosa czyli krótki zarys teorii wizerunku w komunikacji człowieka". Scripta Neophilologica Posnaniensia XVI. 109-124.

Reiß, K. and H.J. Vermeer. 1984. Grundlegung einer allgemeinen Translationstheorie. Tübingen: Niemeyer.

Sampson, E. 1996. Jak tworzyć własny wizerunek. Warszawa: Dom Wydawniczy ABC.

Schill, T.A. 2012. "The visual image and the political image: a review of visual communication research in the field of political communication". The Review of Communication 12(2). 118-142.

Shimp, T.A. 2010. Advertising promotion and other aspects of integrated marketing communications. Mason, $\mathrm{OH}$ : South Western, Cengage Learning.

Smith, P.R. and J. Taylor. 2004. Marketing communications: An integrated approach. London, Sterling/VA: Kogan Page Publishers.

Stróżyński, M. 2001. "Nauczyciel w oczach ucznia”. Edukacja i Dialog 2001/5. 54-60.

Szulczewska, H. 2014. "Tłumacz jak chirurg”. In: Jednym słowem. Blog o wielojęzyczności, uczeniu się i nauczaniu języków obcych. http://www.blogjednymslowem.pl/tlumacz-jak-chirurg/

Swetnam, L.A. 1992. "Media distortion of the teacher image". Clearing House 66(1). 30-32.

Świder, G. 2002. „Wizerunek nauczyciela w wyobrażeniach uczniów szkół średnich w Polsce i w Holandii". Edukacja 2002/2. 28-29.

Tryuk, M. 2006. Przeklad ustny środowiskowy. Warszawa: Wydawnictwo Naukowe PWN.

Uścińska, B. and J. Ciamciara. 2015. Komunikacja wizerunkowa w mediach. Wrocław: Astrum. 
Vermeer, H.J. 1978. „Ein Rahmen für eine allgemeine Translationstheorie”. Lebende Sprachen 23(3). 99-102.

Wadensjö, C. 1998. Interpreting as interaction. London/New York: Longman.

Wheeler, M. 2013. Celebrity politics: Image and identity in contemporary political communications. Cambridge: Polity Press.

Wongphudee, P. 2016. Elements that influence celebrity image building in the entertainment sector of Thailand. RJSH 3(1). 59-72.

Worakijpokatorn, P. 1994. Public relations research. Bangkok: Prakaipruk Publishing.

Wójcik, K. 1997. Public relations od A do Z. Warszawa: Placet.

Wpływ błędów na wizerunek. 2017. https://supertlumacz.pl/wplyw-bledow-na-wizerunek/ 


\section{APPENDIX}

The interview scenario

Information for the interviewee.

The aim of the interview is to collect research material that will be used to write an academic paper, whose goal is to establish how the image of a sworn translator is manufactured, maintained and disseminated in the context of Polish culture. The participation in the research is anonymous. The paper will not reveal any data that may enable anyone to establish the identity of the research participant.

Interview questions:

1. Could you describe your qualifications and professional experience?

2. Could you describe your professional achievements?

3. What types of texts do you usually translate?

4. Do you accept all translation commissions?

5. Do you need more translation commissions?

6. How come you have enough/not enough translation commissions?

7. What activities constitute the process of translating/interpreting performed by you?

8. How do you advertise your offer?

9. Could you describe your contacts with clients?

10. Do you remember any situations when the way you are perceived by others was negatively influenced in any way?

11. Have you planned the process of creating your image in any way? 